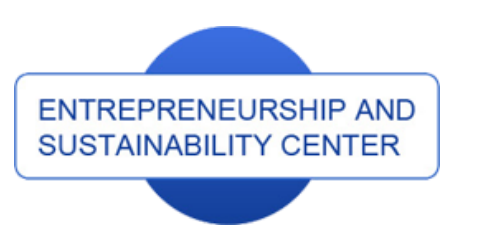

Publisher

http://jssidoi.org/esc/home

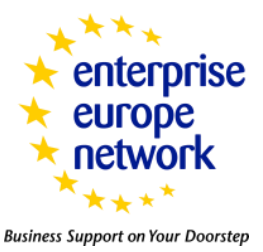

CASPA

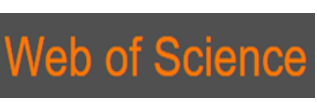

1) Clarivate

\title{
THE EFFECT OF HUMAN AND SOCIAL CAPITAL ON ENTREPRENEURIAL ACTIVITIES: A CASE STUDY OF IRAN AND IMPLICATIONS
}

\author{
Ehsan Chitsaz ${ }^{1}$, Mehdi Tajpour ${ }^{2}$, Elahe Hosseini ${ }^{3}$, Hengameh Khorram ${ }^{4}$, Saloomeh Zorrieh \\ ${ }^{1,2}$ Faculty of Entrepreneurship, University of Tehran, Tehran, Iran \\ ${ }^{3}$ Faculty of Management, Yazd University, Yazd, Iran \\ ${ }^{4,5}$ Islamic Azad University, Tehran Central Branch, Tehran, Iran

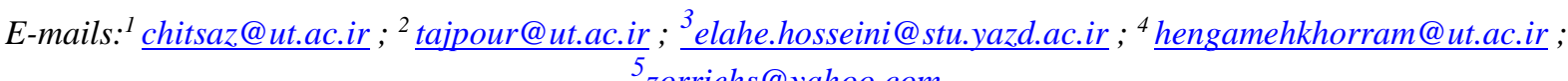 \\ 5 zorriehs@yahoo.com
}

Received 10 August 2018; accepted 10 January 2019; published 30 March 2019

\begin{abstract}
The present study examined two kinds of capital, human and social, on entrepreneurial activities in Hossein Abad Kalpoush Village, Golestan Province, Iran, using primary and secondary data. We used communicative, structural, and cognitive dimensions to evaluate social capital, while we focused on knowledge, skills, and self-efficacy to investigate human capital. Entrepreneurship development is a complex, long-term, and comprehensive procedure with a major role in the economic development of countries. It has turned into the most strategic and major tool for economic promotion in developed countries. Studies on entrepreneurship have proved that there is a correlation between the rate of entrepreneurship activities and national gross product in some countries. Consequently, it is always accompanied by an enhancement of national income and welfare. Entrepreneurship reveals the opportunities, threats, and weak and strong points of environments, including agriculture, by means of a novel methodology and policymaking in order to revolutionize them. This evolution is accompanied by the presentation of new ideas and methods to solve existing and future problems, thereby improving farmers' economic conditions. The results of this study showed the significant effect of dimensions of human and social capital on entrepreneurial activities.
\end{abstract}

Keywords: entrepreneurship development; rural entrepreneurship; self-efficiency; social capital

Reference to this paper should be made as follows: Chitsaz, E.; Tajpour, M.; Hosseini, E.; Khorram, H.; Zorrieh, S. 2019. The Effect of human and social capital on entrepreneurial activities: a case study of Iran and implications, Entrepreneurship and Sustainability Issues 6(3): 1393-1403. http://doi.org/10.9770/jesi.2019.6.3(24)

JEL Classifications: L26, E71, A13

Additional disciplines: sociology

\section{Introduction}

Rural development is one of the main priorities of different countries, especially developing ones, and requires a systematic and efficient plan rather than a simple strategy (Tipple, 2006). Many researchers believe that developing various types of entrepreneurship activities in rural areas creates more jobs, produces capital, assists 


\section{ENTREPRENEURSHIP AND SUSTAINABILITY ISSUES}

ISSN 2345-0282 (online) http://jssidoi.org/jesi/

2019 Volume 6 Number 3 (March)

http://doi.org/10.9770/jesi.2019.6.3(24)

fair income distribution, and decreases poverty, thereby playing a key role in rural and national development (Najafi \& Safa, 2015).

Entrepreneurship is one of the factors affecting rural job creation and development as it creates new jobs to rebuild the economic condition in villages (Tousi et al, 2014). Almost all societies agree that they must strengthen the creation and development of entrepreneurship. Accordingly, they propose various views and methods which can be adopted based on social conditions (Sobel \& King, 2008).

Tousi et al. (2014) believe that entrepreneurship in rural areas is not an easy task because of certain restrictions since the concept of entrepreneurship has not been defined in villages despite the presence of many hardworking, innovative, and creative people. This is because of the unfamiliarity with or rejection of entrepreneurship, lack of financial support, lack of access to accurate information, absence of a supportive culture, and a long distance between villages and markets and services. One of the best ways to develop entrepreneurship in rural young generations is focusing on their entrepreneurial features and changing their attitudes towards the creation of new businesses and new jobs based on innovativeness (the tendency to present new ideas), risk-taking (acceptance of unpredictable hazards), inclination to autonomy (concept of self-employment), initiation (being the market leader), and taking an offensive approach (the power of dealing with difficult challenges), thereby developing entrepreneurship (Dess \& Lumpkin, 1996, as cited in Talebi et al, 2015).

Opportunities exists in the environment and wait to be discovered, and those with a superior human capital can discover these opportunities (Bhagavatula et al, 2010, Chitsaz, Liang, \& Khoshsoroor, 2017). In other words, those who enjoy a high level of human capital will identify more businesses in a given period of time. Human capital is defined as a series of knowledge and skills acting as input which leads to outputs such as decisions for self-employment and developing entrepreneurial activities (Ucbasaran et al, 2008). On the other hand, social capital largely depends on social and cultural factors, and if people identify it as a form of capital (either in macro-management or in the management of organizations), they will attain a new understanding of socioeconomic systems which will help managers towards a better leadership. Such a capital plays a pivotal role in developing entrepreneurial activities as it is a social and economic process which depends on social conditions and context in two ways: a) Entrepreneurs are affected by their own social environment; and b) entrepreneurship is a social activity that is intertwined with social links which affect the nature of businesses (Adler \& Kwon, 2002).

With regard to the issues discussed in theoretical research on entrepreneurship development for rural youth, the examination of effective factors can accelerate the entrepreneurship process in villages and reduce employment problems. Previous studies have separately investigated the effect of human capital and social capital on entrepreneurship development, and no comprehensive study is available on the simultaneous effect of these two factors. The present study, therefore, examined both dimensions to see whether human and social capital affect the entrepreneurial activities among young people in Hossein Abad Kalpoush village, Golestan Province, Iran. To this end, we used the descriptive-analytical research method along with structural equation modeling. The rest of this paper is organized as follows: First, we review the literature to enumerate the valuable components related to the research topic. Then, we examine the details of method and results. Finally, we present discussions and conclusions and offer suggestions for future studies to policymakers in the domain of science and industry. 


\section{ENTREPRENEURSHIP AND SUSTAINABILITY ISSUES}

ISSN 2345-0282 (online) http://jssidoi.org/jesi/

2019 Volume 6 Number 3 (March)

http://doi.org/10.9770/jesi.2019.6.3(24)

\section{Literature review}

Generally speaking, there is no difference between rural entrepreneurship and the notion of entrepreneurship in general. The only difference lies in the special conditions of rural areas, including the high risk, lack of facilities, and weak management. Rural entrepreneurship seeks to identify new opportunities, innovation, creativity in agricultural and non-agricultural activities, and the optimal, diverse, and innovative land use in line with rural development.

A method of rural development is entrepreneurship because it significantly affects rural economy and welfare by creating numerous job opportunities. That is why the evaluation of rural entrepreneurship level and its promotion are of special importance for rural development. Although entrepreneurship may have different positive outcomes in rural communities, as a socio-economic and cultural phenomenon, it is itself affected by other contexts, factors, and skills. In other words, the emergence of entrepreneurship in a society depends on different contexts and factors.

Goldin and Katz state that the 20th century was the era of human capital (Acemoglu \& Autor, 2012). In this century, human capital became known as the most important asset and resource for creativity and innovation Human capital affects the growth of societies more than any other factor and is a major motivation for people to choose careers (Estrin et al, 2016). Human capital includes different skills and capabilities such as professional knowledge (Lin, 2011). It can be claimed that human capital shows one's acquired knowledge, created through competency, attitudes, mental agility, and problem-solving skills, and is an important resource for firms' innovation and regeneration (Unger et al., 2011). Human capital is nor a physical, neither a financial capital but the knowledge, skill, and self-efficacy of individuals (Hossein Pour and Abdollahi, 2015). Those who have higher knowledge, skills, and self-efficacy, act with more innovation and solve problems more quickly (Alpkan et al, 2010).

Thus, the first hypothesis is formed as follows:

Hypothesis 1: An increase in Human capital leads to a development of entrepreneurship activities.

Social capital includes concepts such as networks, trust, cooperation, participation, equity, responsibility and responsiveness, and commitment and cooperation among community members, estimated as a structure which influences the development of entrepreneurial activities (Cao et al, 2015). It is more than a group of social organizations or social values and often promotes output by increasing the productivity of other sources, including physical and human capital. Social capital is a set of institutions, relationships, and regulations which shape the quality and quantity of social interactions in the society (Ali Abadi et al, 2016). It is alternatively defined as an essential and valuable resource that extends the work environment and investment on which is the key to development (Sainaghi \& Baggio, 2014).

Nahapiiet and Ghoshal (1998) consider social capital as a series of sources which come into existence through relationships among people. They assume three dimensions for social capital using an organizational view: communicative (relationships among people because of their history of interactions), cognitive (goals, visions, and common values between users in a social system), and structural (the combination of relationships between people and units that means how and to whom someone has access). When people belong to a community with a high level of social capital, they tend to cooperate with one another more and undertake riskier affairs. This rich social capital expands creative and innovative activities and leads to a better performance (Farsi et al, 2013). Hence, the following hypothesis is formed: 


\section{ENTREPRENEURSHIP AND SUSTAINABILITY ISSUES}

ISSN 2345-0282 (online) http://jssidoi.org/jesi/

2019 Volume 6 Number 3 (March)

http://doi.org/10.9770/jesi.2019.6.3(24)

Hypothesis 2: An increase in Social capital leads to a development of entrepreneurship activities.

Entrepreneurship exists in various environments, leading to economical growth through a variety of innovations created by people in response to economic situations (Shepherd et al, 2008). It happens in rural areas based on the facilities and environment of villages. According to Pato and Teixeira (2014), rural entrepreneurship means the creation of new businesses, which introduce new products or services, markets, and use of new technologies in villages.

Kai and Jao (2016) concluded that social capital and its dimensions such as communicative, structural, and cognitive capital, impact the entrepreneurship of individuals in China. Moreover, Saleh et al. (2016) examined the relationship between social capital and entrepreneurship for empowerment and concluded that it stimulates entrepreneurship in people and consequently empowers them. Also, in their descriptive studies, Zhang et al. (2015) and Saleem et al. (2018) showed that social norms, control behavior, interpersonal social capital, and social welfare, affecting the development of entrepreneurial intentions in people.

Engelen et al. (2015) noted that, as a social feature, social capital can lead to creativity and innovation and facilitates entrepreneurial behavior in people. In addition, Barnier (2012) examined some influential elements affecting individuals' decisions regarding businesses and identified human capital as a major factor for the establishment of entrepreneurial businesses. In a study exploring entrepreneurship in China, Tang (2010) concluded that individuals who have a high human and social capital and social skills discover more entrepreneurship opportunities Furthermore, Alpekan and et al. (2010) found that human capital has a significant impact on innovative behaviors among Turkish companies.

It is believed that entrepreneurship development is a process formed by human and social capital (Hindle et al., 2010). Human capital enhances entrepreneurs' ability to take advantage of new opportunities and helps them access physical and financial resources much easier and acquire new knowledge and skills. Ucbasaran et al. (2008) examined entrepreneurial opportunities and concluded that the different dimensions of human capital are related to the identification and incorporation of entrepreneurship opportunities.

Aliabadi et al. (2017) concluded that social capital and its dimensions such as cooperation, coherence, safety, social trust, social and cultural values, valuing life, and communications impact the entrepreneurship of rural youth in Kangaver, Iran. Moreover, Kheirandish and Jamshidi (2017) stated that social capital in organizations and strengthening trust-based communications can enhance entrepreneurial activities. Hosseinpour and Mohammadi (2016) also concluded that human capital is known as a potential resource for encouraging entrepreneurial behaviors in organizations. Finally, according to Yadollahi Farsi et al. (2013), human capital and social capital are among the most important elements in the development of entrepreneurship among rural youths in Korbal, Iran. Based on the literature review, the conceptual model of the present study is presented as follows (Figure 1): 


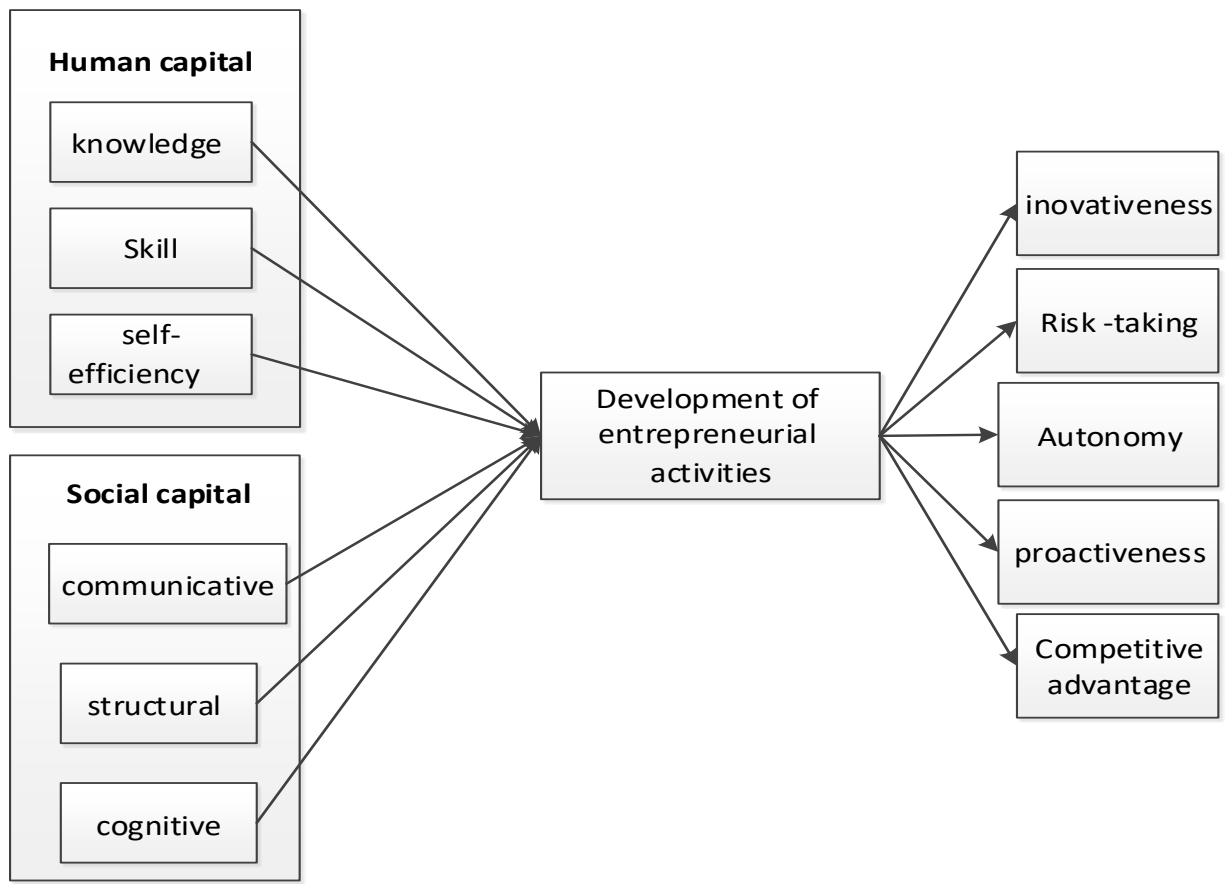

Figure 1. The conceptual model of the study

\section{Research Method}

The present research is applied in terms of objective and descriptive-analytic with structural equation modeling in terms of data collection. In this study, the effect of variables was analyzed based on coefficients determined in structural equations. Data were collected through the field study method using questionnaires. Finally, we utilized Smart PLS to evaluate and model the relationships among variables.

The data collecting instrument was a standard 36-item questionnaire scored on a five-point Likert scale (Table 1).

Table 1. Data Collection Instrument

\begin{tabular}{|l|l|l|}
\hline Variables & Authors & Number of Items \\
\hline Human Capital & Hosseinpour and Abdollahi (2015) & 9 \\
\hline Social Capital & Nahapiiet and Ghoshal (1998) & 12 \\
\hline Entrepreneurial activities & Dess and Lumpkin (1996) & 15 \\
\hline
\end{tabular}

Experts reviewed the first edition of the questionnaire in order to confirm its content and face validity and corrections were applied based on their comments.

In order to fit and test the hypotheses using structural models, we used the partial least squares (PLS) method using Smart PLS software (Chitsaz \& Dapeng, khishsoroor, 2016). This method seems to be the best tool for analyzing studies with a small sample size and complex variables. To analyze the models in this method, we had to examine the fit of the model first and then test the research hypotheses. The fit of the model is examined in two parts: measurement model and structural model (Davari \& Rezazadeh, 2013). We employed three indexes of reliability, convergent validity, and divergent validity to assess the fit of the measurement model, and examined combined reliability and Cronbach's alpha to assess model reliability. Results are presented in Table 2. 
ENTREPRENEURSHIP AND SUSTAINABILITY ISSUES

ISSN 2345-0282 (online) http://jssidoi.org/jesi/

2019 Volume 6 Number 3 (March)

http://doi.org/10.9770/jesi.2019.6.3(24)

Table 2. The reliability of research constructs

\begin{tabular}{|l|l|l|}
\hline Research variables & Cronbach's alpha coefficient & Combined reliability \\
\hline Human Capital & 0.91 & 0.83 \\
\hline Social Capital & 0.93 & 0.79 \\
\hline Entrepreneurial activities & 0.86 & 0.74 \\
\hline
\end{tabular}

Based on Table 2, it is clear that all variables have a high reliability and the combined reliability and Cronbach's alpha in all cases are above 0.7 , proving that research instruments have an appropriate fit.

The validity of the questionnaire was explored using convergent and divergent validity which are specific to structural equation modeling. The criterion of AVE (average variance extracted) shows the correlation of a construct with its own indices. The higher this correlation, the higher the fit. The value of AVE for research constructs is presented in Table 3. In divergent validity, the correlation of a construct with its indices is compared with its correlation with other constructs. The results of divergent validity are depicted in Table 3 .

Table 3. The convergent and divergent validity of research constructs

\begin{tabular}{|c|c|c|c|c|c|c|c|c|c|}
\hline Constructs & 1 & 2 & 3 & 4 & 5 & 6 & 7 & 8 & 9 \\
\hline AVE & 58.0 & 61.0 & 73.0 & 59.0 & 64.0 & 71.0 & 58.0 & 59.0 & 70.0 \\
\hline 1. Human Capital & 76.0 & & & & & & & & \\
\hline 2. Knowledge & 46.0 & 78.0 & & & & & & & \\
\hline 3. Skill & 58.0 & 41.0 & 85.0 & & & & & & \\
\hline 4. Self-efficiency & 47.0 & 52.0 & 42.0 & 76.0 & & & & & \\
\hline 5. Social Capital & 44.0 & 38.0 & 51.0 & 59.0 & 80.0 & & & & \\
\hline 6. Cognitive dimension & 32.0 & 38.0 & 34.0 & 47.0 & 63.0 & 84.0 & & & \\
\hline 7. structural dimension & 27.0 & 34.0 & 29.0 & 33.0 & 58.0 & 56.0 & 76.0 & & \\
\hline 8.Communicative dimension & 43.0 & 36.0 & 46.0 & 27.0 & 47.0 & 57.0 & 63.0 & 76.0 & \\
\hline 9.Entrepreneurial activities & 29.0 & 22.0 & 37.0 & 41.0 & 46.0 & 38.0 & 59.0 & 39.0 & 83.0 \\
\hline
\end{tabular}

The results in Table 3 prove that the AVE of all constructs is higher than 0.5, confirming the model's convergent validity and the fit of measurement models. Also, results of divergent validity (in the main diagonal matrix) show that research constructs have a higher degree of interaction with their own indices compared with other constructs, and thus the divergent validity of the model is acceptable.

\section{Results}

The young people in Hossein Abad Kalpoush village, Golestan Province, made up the statistical population of this study. Ninety people were selected through simple random sampling due to restricted access to young people in rural areas. Next, we examined the relations between the variables using the PLS and results were recorded in two modes of T-values and standardized estimation. First, we utilized the Bootstrapping command in Smart PLS to confirm the research hypotheses. The output shows the sum of T-coefficients (Figure 2). When the value of $\mathrm{T}$ is more than +1.96 or less than -1.96 , the parameter is significant and research hypotheses are confirmed. We can clearly understand from Figure 2 that all T-coefficients among variables (numbers in parentheses) are higher than 1.96, confirming the research hypotheses. Then, we assessed the cause-and-effect relation between research constructs using Smart PLS (standardized estimation). Based on Figure 2, there is a significant positive relationship between variables. Thus, human and social capital have positive and significant effects on the development of entrepreneurial activities. A brief summary is provided in Table 4 . 


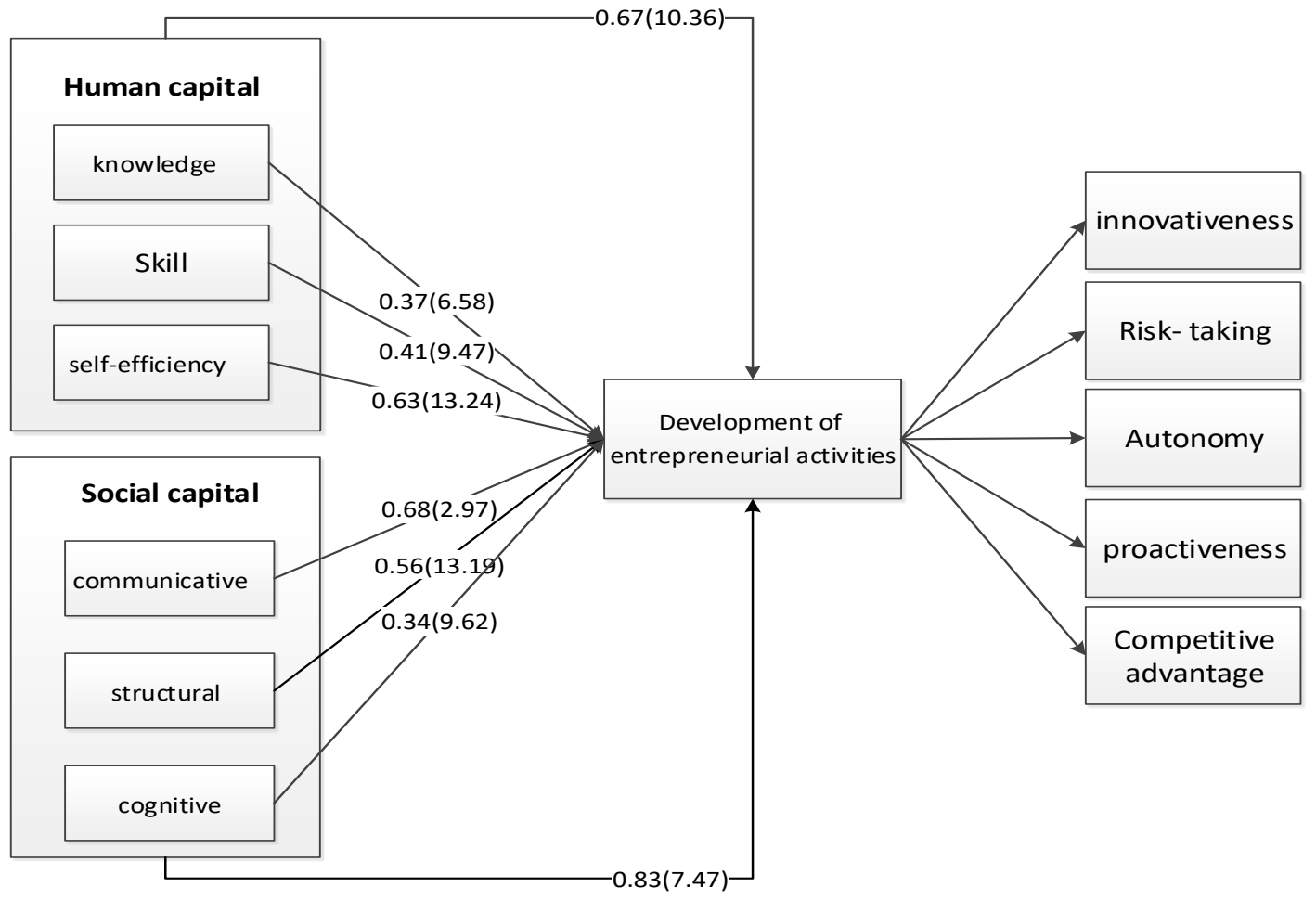

Figure 2. Execution of the model in two models of t-values and standardized estimation

The results of model execution in two modes of T-values and standardized estimation are presented in Table 4.

Table 4. Results of testing the research hypotheses

\begin{tabular}{|l|l|l|l|}
\hline Hypotheses & $\begin{array}{l}\text { T-value } \\
\text { statistic }\end{array}$ & $\begin{array}{l}\text { Standardized } \\
\text { Coefficients }\end{array}$ & Hypothesis \\
\hline Human Capital $\Rightarrow$ Development of entrepreneurial activities & 10.36 & 0.67 & hypothesis approved \\
\hline Social Capital $\Rightarrow$ Development of entrepreneurial activities & 7.47 & 0.83 & hypothesis approved \\
\hline Knowledge $\Rightarrow$ Development of entrepreneurial activities & 6.58 & 0.37 & hypothesis approved \\
\hline Skills $\Rightarrow$ Development of entrepreneurial activities & 9.47 & 0.41 & hypothesis approved \\
\hline Self-efficiency $\Rightarrow$ Development of entrepreneurial activities & 13.24 & 0.63 & hypothesis approved \\
\hline Communicative dimension $\Rightarrow$ Development of entrepreneurial activities & 2.97 & 0.68 & hypothesis approved \\
\hline Structural dimension $\Rightarrow$ Development of entrepreneurial activities & 13.19 & 0.56 & hypothesis approved \\
\hline Cognitive dimension $\Rightarrow$ Development of entrepreneurial activities & 9.62 & 0.34 & hypothesis approved \\
\hline
\end{tabular}

\section{Discussion and Conclusion}

The main objective of the present research was examining the effect of human and social capital on the development of entrepreneurial activities in an applied study. The sample comprised 90 residents of Hossein Abad Kalpoush village in Golestan Province who filled out a questionnaire scored on a five-point Likert scale. Results were analyzed using a structural equation modeling software.

As mentioned before, modern societies changed dramatically compared to the past. Therefore, it is necessary to look for elements which may contribute to the development of entrepreneurial activities. Results of the first 


\section{ENTREPRENEURSHIP AND SUSTAINABILITY ISSUES}

ISSN 2345-0282 (online) http://jssidoi.org/jesi/

2019 Volume 6 Number 3 (March)

http://doi.org/10.9770/jesi.2019.6.3(24)

hypothesis (i.e. the impact of human capital on the development of entrepreneurial activities) and sub-hypotheses of human capital dimensions indicated that human capital and its dimensions such as knowledge, skills, and selfefficiency influence the development of rural youths' entrepreneurial activities. Consequently, one of the factors affecting the development of entrepreneurial activities is human capital which not only prepares the conditions for identification, evaluation, and exploitation of diverse entrepreneurship opportunities, but also affects people's entrepreneurial intention and behaviors. In line with this hypothesis, Hindle et al. (2009) assert that the process of entrepreneurship development is formed by human capital. Also, Atger et al. (2011) contend that human capital increases competencies for discovering and utilizing opportunities and helps people access other useful physical and financial resources easier and acquire new skills and knowledge. Consistent with the present study, results of Barnier's (2012) and Hosseinpour and Mohammadi's (2015) studies showed that human capital with knowledge, skills, and self-efficiency can lead to entrepreneurial behaviors. Therefore, we conclude that human capital as an input leads to outputs such as decision for self-employment and development of entrepreneurial activities among the rural youth.

Results of the second hypothesis (i.e. the impact of social capital on the development of entrepreneurial activities) and its sub-hypotheses related to social capital dimensions indicated that dimensions of social capital (cognitive, structural, and communicative) can affect the development of rural youth' entrepreneurial activities. Social capital refers to the connections and communications among members in a community. It helps members realize their goals by creating norms and mutual trust. Societies which enjoy a good social capital affect the information exchange and knowledge distribution among society members and thus lead to novel opinions and creativity, thereby resulting in the development of entrepreneurial activities. Results of this hypothesis were consistent with studies by Zhang et al. (2015), Engelen et al. (2015), Cai et al. (2016) who concluded that attention to social norms, restricted behaviors, and social capital promotes entrepreneurial behaviors. Moreover, results of the present study were confirmed by Abdollahi et al. (2016) and Kheirandish and Jamshidi (2015) who concluded that social capital is a key factor in entrepreneurship development.

Based on the results of hypotheses, the following suggestions are made: To enhance human capital, knowledge, skills, and self-efficiency must be highlighted in youths in villages. Decision-makers can enhance these indices by holding entrepreneurship and business planning courses. They can also distribute booklets to enhance the knowledge of rural youth. To promote social capital, information can be shared among young people using communication networks inside and outside villages to enhance innovativeness and new opportunities. Moreover, encouragement for establishing social institutions is a structural solution to promote social capital. In these institutions, people find a common identity to advance group cooperation. Such institutions can be created in organizations and businesses at the individual and group level. Furthermore, professional and specialized groups and associations can promote social capital.

\section{References}

Acemoglu, D., Autor, D. (2012). What Does Human Capital Do? A Review of Goldin and Katz's The Race between Education and Technology. Journal of Economic Literature, 50(2), 426-463. https://doi.org/10.3386/w17820

Adler, P. S., \& Kwon, S. W. (2002). Social capital: Prospects for a new concept. Academy Of Management Review, 27(1), 17-40. https://doi.org/10.2307/4134367

AliAbadi, V; Ataei, P; Movahedi, R, (2017). The Effect of Strategic Thinking and Social Capital on the Recognition of Entrepreneurial Opportunities among Rural Youth, Rural Research and Planning, 5(2), 110-95.

Alpkan, L., Bulut, C., Gunday, G., Ulusoy, G., Kilic, K. (2010). Organizational support for intrapreneurship and its interaction with human capital to enhance innovative performance. Management decision, 48(5), 732-755, https://doi.org/10.1108/00251741011043902 


\section{ENTREPRENEURSHIP AND SUSTAINABILITY ISSUES}

ISSN 2345-0282 (online) http://jssidoi.org/jesi/

2019 Volume 6 Number 3 (March)

http://doi.org/10.9770/jesi.2019.6.3(24)

BarNir, A. (2012). Starting technologically innovative ventures: reasons, human capital, and gender. Management Decision, 50(3), 399419, https://doi.org/10.1108/00251741211216205

Cai, W., \& Zhao, H. (2016). Verification for Mediating Effect of Informal Finance between Social Capital and Entrepreneurship: Empirical Analysis Based on China's Provincial Panel Data. Available at SSRN 2759411, https://doi.org/10.2139/ssrn.2759411

Cao, Q., Simsek, Z., \& Jansen, J. J. (2015). CEO social capital and entrepreneurial orientation of the firm: Bonding and bridging effects. Journal of Management, 41(7), 1957-1981, https://doi.org/10.1177/0149206312469666

Chitsaz, E., Liang, D., \& Khoshsoroor, S. (2017). The impact of resource configuration on Iranian technology venture performance.

Technological Forecasting and Social Change, 122, 186-195, https://doi.org/10.1016/j.techfore.2016.03.009

Davari, A; Rezazadeh, A, (2013). Modeling Structural Equations with PLS Software, Tehran: Jahad University Press.

Engelen, A., Kaulfersch, A., \& Schmidt, S. (2015). The Contingent Role of Top Management's Social Capital on the Relationship between Entrepreneurial Orientation and Performance. Journal of Small Business Management, https://doi.org/10.2139/ssrn.2041101

Estrin, S., Mickiewicz, T., \& Stephan, U. (2016). Human capital in social and commercial entrepreneurship. Journal of Business Venturing, 31(4), 449-467, https://doi.org/10.1016/j.jbusvent.2016.05.003

Farsi, J. Y; Razavi, SM, (2012). The Role of Social Capital and Human Capital in Youth Entrepreneurship in the Villages of the Karbala District, Human Resource Studies, 79, 115-103.

Farsi, J. Y., Rezazadeh, A., \& Najmabadi, A. D. (2013). Social capital and organizational innovation: The mediating effect of entrepreneurial orientation. Journal of Community Positive Practices, 13(2), 22-40, https://doi.org/10.2139/ssrn.2490385

Hindle, K., Klyver, K., \& Jennings, D. F. (2009). An “informed” intent model: Incorporating human capital, social capital, and gender variables into the theoretical model of entrepreneurial intentions. In Understanding the entrepreneurial mind (pp. 35-50). Springer New York, https://doi.org/10.1007/978-1-4419-0443-0_3

Hosseinpour, D, Abdollahi, M, (2015). The Impact of Human Capital on the Incidence of Entrepreneurial Behavior, Management Studies, 24(78), 126-109.

Kherandish, M, Jamshidi, H, (2016). The Impact of Social Capital on Organizational Entrepreneurship by Intermediating Job Engagement, Social Capital Management, 3(1), 68-43.

KheiAndish, M \& RezaZadeh, A, (2013). Structural Equation Modeling along PLS, Tehran: Jahad Daneshgahi publication.

Khoshsoroor, S., Chitsaz, E., Dapeng, L., \& Alizadeh, H. (2017). How can Risk Propensity Mediate the Effect of Trait Anxiety on Entrapment Behavior? Proceedings of the International Conference on Business and Information Management - ICBIM 2017. https://doi.org/10.1145/3134271.3134291

Khoshsoroor, S., Dapeng, L., \& Chitsaz, E. (2016). Propositions on Resource Allocation in Teams. In Proceedings of the 2016 8th International Conference on Information Management and Engineering (pp. 57-61). ACM, https://doi.org/10.1145/3012258.3012265

Lin, C. P. (2011). Modeling job effectiveness and its antecedents from a social capital perspective: A survey of virtual teams within business organizations. Computers in Human Behavior, 27(2), 915-923, https://doi.org/10.1016/j.chb.2010.11.017

Lumpkin, G. T., \& Dess, G. G. (1996).Clarifying the entrepreneurial orientation construct and linking it to performance. Academy of Management Review, 21(1), 135-172, https://doi.org/10.2307/258632

Manzor, D, Yadipour, M, (2009). Social Capital of Social and Economic Development, Jasmine Strategic Quarterly, 15, 162-140

Najafi, B; Safa, L, (2013). An Investigation of Entrepreneurial Home Businesses and Obstacles and Challenges for their Development in Rural Areas, Agricultural Entrepreneurship Journal, 1(2), 73-61

Nahapiiet, J., \& Ghoshal, S. (1998), Social capital, Intellectual capital \& the organizational advantage, Academy of Management Review, 23(2), 242-260, https://doi.org/10.2307/259373 


\section{ENTREPRENEURSHIP AND SUSTAINABILITY ISSUES}

ISSN 2345-0282 (online) http://jssidoi.org/jesi/

2019 Volume 6 Number 3 (March)

http://doi.org/10.9770/jesi.2019.6.3(24)

Pato, M. L., \& Teixeira, A. A. (2014). Twenty years of rural entrepreneurship: a bibliometric survey. Sociologia Ruralis, https://doi.org/10.1111/soru.12058

Sainaghi, R., \& Baggio, R. (2014). Structural social capital and hotel performance: Is there a link?. International Journal of Hospitality Management, 37, 99-110, https://doi.org/10.1016/j.ijhm.2013.11.004

Saleh, A., Metalisa, R., \& Mukhlishah, N. (2016). Correlation between Social Capital and Entrepreneurship toward Posdaya Empowerment. Pertanika Journal of Social Sciences \& Humanities, 24(1).

Saleem, F., Adeel, A., Rizwan A., Hyder, S. (2018). Intentions to adopt ecopreneurship: moderating role of collectivism and altruism. Entrepreneurship and Sustainability Issues, 6(2), 517-537. http://doi.org/10.9770/jesi.2018.6.2(4)

Shepherd, D. A., Covin, G, F., \& Kuratko F. D. (2008). Project failure from corporate entrepreneurship: Managing the Grief process. Journal of Business Venturing, 24(6), 588-600, https://doi.org/10.1016/j.jbusvent.2008.01.009

Sobel, R. S., \& King, K. A. (2008). Does school choice increase the rate of youth entrepreneurship? Economics of Education Review, 27(4), 429-438, https://doi.org/10.1016/j.econedurev.2007.01.005

Talebi, K., Rezazadeh, A., \& Najmabadi, A. D. (2015). SME alliance performance: The impacts of alliance entrepreneurship, entrepreneurial orientation, and intellectual capital. International Journal of Entrepreneurship and Small Business, 24(2), 187-207, https://doi.org/10.1504/ijesb.2015.067286

Tang, J. (2010). How entrepreneurs discover opportunities in China: An institutional view. Asia Pacific Journal of Management, 27(3), 461-479, https://doi.org/10.1007/s10490-009-9151-6

Tipple, G. (2006). Employment and work conditions in home-based enterprises in four developing countries: do they constitute 'decent work'?. Work, Employment and Society, 20(1), 167-179, https://doi.org/10.1177/0950017006061280

Tousi, Ramezan \& Jamshidi, Ali Reza \& Taghdisi, Ahmad (2014). The rural entrepreneurship and determining the effective elements on it, Research and Rural Planning, 3(8), 1-12, https://doi.org/10.22495/rgcv8ilart4

Ucbasaran, D., Westhead, P., \& Wright, M. (2008). Opportunity identification and pursuit: does an entrepreneur's human capital matter?. Small Business Economics, 30(2), 153-173, https://doi.org/10.1007/s11187-006-9020-3

Unger, J. M., Rauch, A., Frese, M., \& Rosenbusch, N. (2011). Human capital and entrepreneurial success: A meta-analytical review. Journal of Business Venturing, 26(3), 341-358, https://doi.org/10.1016/j.jbusvent.2009.09.004

Zhang, P., Wang, D. D., \& Owen, C. L. (2015). A study of entrepreneurial intention of university students. Entrepreneurship Research Journal, 5(1), 61-82, https://doi.org/10.1515/erj-2014-0004 


\section{ENTREPRENEURSHIP AND SUSTAINABILITY ISSUES}

ISSN 2345-0282 (online) http://jssidoi.org/jesi/

2019 Volume 6 Number 3 (March)

http://doi.org/10.9770/jesi.2019.6.3(24)

Short biographical note about the contributors at the end of the article (name, surname, academic title and scientific degree, duties, research interests):

Ehsan CHITSAZ is the faculty member for Entrepreneurship management and the general directorate for Planning, budgeting and organization analysis, University of Tehran. His primary research program involves the study of entrepreneurial decision making in dynamic environment. He is currently studying (a) the variables that influence the identification of causes in continuously unfolding environments and (b) the situational and individual variables related to impulsive and risky choice in video game environment. Ehsan does research in Social Psychology, Cognitive Psychology and Behavioral Science. His current project is 'Decryption of the Role of Situational Factors and Personality Traits in the Competition'. He got several awards including outstanding researcher in China.

ORCID ID: https://orcid.org/0000-0002-9656-418X

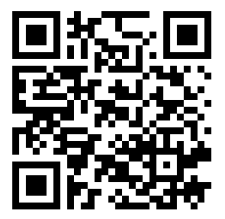

Mehdi TAJPOUR is a PhD candidate in Entrepreneurship management, University of Tehran. His research program about rural entrepreneurship, emotional intelligence, spiritual intelligence and the Internet of Things, Entrepreneurial University, human resource management and Corporate Entrepreneurship. The title of my doctoral thesis is about the internationalization of universities in Iran.

ORCID ID: https://orcid.org/ 0000-0001-8951-9711

Elahe HOSSEINi is a PhD candidate in Management, Yazd Univerity. Her research interest is rural entrepreneurship, human resource management and social activities to develop entrepreneurship in developing countries.

ORCID ID: https://orcid.org/0000-0003-3478-5320

Hengameh KHORRAM is a Ph. D Candidate of International entrepreneurship, MA in Entrepreneurship from Tehran University, BA in Midwifery from Shiraz Medical School \& both BA and MA in English translation. Interested in IOT and Corporate entrepreneurship especially in banking system since I've been a bank officer for the last 22 years. My dissertation is about designing a Model for developing entrepreneurship in order to create value in banking system.

ORCID ID: $\underline{\text { https://orcid.org/0000-0001-9037-1670 }}$

Saloomeh ZORRIEH is a $\mathrm{PhD}$ candidate in International Entrepreneurship Management, Islamic Azad University, Tehran Central Branch, Tehran. He has a history of management in an organizational and non-institutional sector. Her research interest is entrepreneurship and creativity and organizational behavior and human resource management.

ORCID ID: $\underline{\text { https://orcid.org/0000-0002-3433-5381 }}$

Copyright (C) 2019 by author(s) and VsI Entrepreneurship and Sustainability Center

This work is licensed under the Creative Commons Attribution International License (CC BY).

http://creativecommons.org/licenses/by/4.0/

cC) $\underset{\mathrm{EY}}{\text { (7) Open Access }}$ 